Article

\title{
Prevalence, Genotype Distribution, and Predictors against HPV Infections Targeted by 2-, 4-, 9-Valent HPV Vaccines among Japanese Males
}

\author{
Yukimasa Matsuzawa ${ }^{1}\left(\mathbb{D}\right.$, Tadaichi Kitamura ${ }^{1,2,3}$, Motofumi Suzuki ${ }^{1, *(\mathbb{D})}$, Yasuhiro Koyama ${ }^{4}$ \\ and Kazuyoshi Shigehara ${ }^{5}$ \\ 1 Department of Urology, University of Tokyo Hospital, Bunkyo-ku, Tokyo 113-0033, Japan; \\ ymatsuza@ims.u-tokyo.ac.jp (Y.M.); tadkitamura-tky@umin.ac.jp (T.K.) \\ 2 Japanese Foundation for Sexual Health Medicine, Bunkyo-ku, Tokyo 113-0034, Japan \\ 3 Department of Urology, Nagareyama Central Hospital, Nagareyama, Chiba 270-0114, Japan \\ 4 Department of Urology, Asoka Hospital, Koto-ku, Tokyo 135-0002, Japan; yc_ask@hotmail.co.jp \\ 5 Department of Urology, Faculty of Medicine, Kanazawa University, Kanazawa 920-8641, Japan; \\ kshigehara0415@yahoo.co.jp \\ * Correspondence: suzukim-uro@h.u-tokyo.ac.jp; Tel.: +81-3-5800-8753
}

Received: 30 March 2020; Accepted: 12 May 2020; Published: 14 May 2020

\begin{abstract}
Objectives: Epidemiological reports of sexual life and human papilloma virus (HPV) infection among Japanese men are scarce, and the necessity of HPV vaccines for males is regarded as a controversial topic in Japan. The objective of this study is to determine the prevalence, genotype distribution, and risk factors against HPV infections targeted by bivalent $(2 \mathrm{v})$, quadrivalent $(4 \mathrm{v})$, and 9-valent $(9 \mathrm{v}) \mathrm{HPV}$ vaccines among Japanese male patients who visited our urological clinics. Material and Methods: The study population consisted of 798 males aged 20 to 95 years (mean \pm standard deviation, $55.4 \pm 19.5$ years). We collected scraping samples from the glans penis using cotton swabs from all patients for genotyping of HPVs. We compared patients' characteristics and detected HPV genotypes in order to determine the risk factors against HPV infections. Results: Of 798 participants, 198 participants $(198 / 798 ; 24.8 \%)$ had at least one genotype of any HPV infection. The total number of detected HPV genotypes was 328 . Of 328 genotypes, $30 \%(n=99 ; 99 / 328)$ were $9 \mathrm{v}$ HPV genotypes. Most frequently detected types of high-risk HPV infection were type $52(\mathrm{n}=40$; $40 / 328 ; 12.2 \%)$. Number of lifetime sex partners $(\geq 21)$ and present or history of sexually transmitted infections were found to be predictors of any HPV infection with adjusted odds ratios of 3.106 (95\% confidence interval (CI), 1.593-6.509) and 1.894 (95\% CI, 1.185-3.026), respectively. Age of sex initiation was a predictor of $2 \mathrm{v}$ and $4 \mathrm{v}$ HPV infections with adjusted odds ratios of 100 ( $95 \% \mathrm{CI}, 1.013-25.673$ ) and 2.676 (95\% CI, 1.037-6.905), respectively. Number of lifetime sex partners ( $\geq 21)$ was a predictor of $9 \mathrm{v} \mathrm{HPVs}$ with adjusted odds ratios of 2.397 (95\% CI, 1.060-5.424). Conclusions: Approximately, a quarter of Japanese male patients who visited urological clinics were exposed to HPV. Moreover, from the perspective of our multivariate logistic regression analysis, some kinds of sexual behavior aggravate the risk of typical HPV genotypes infections.
\end{abstract}

Keywords: human papillomavirus; $\mathrm{HPV}$ vaccine; $2 \mathrm{v}$ vaccine; $4 \mathrm{v}$ vaccine; $9 \mathrm{v}$ vaccine

\section{Introduction}

More than 200 genotypes of human papilloma virus (HPV) have been identified to date [1]. Sexually transmitted HPV genotypes were classified into two groups, low-risk (LR) and high-risk (HR) types [2]. LR HPVs can cause warts around genitals, anus, mouth, and throat. On the other hand, long-lasting infection with HR HPVs can cause anogenital tract cancers, oropharyngeal cancers, 
and nonmelanoma skin cancers [3]. Each year, approximately 34,800 new cases of HPV-associated cancer were found in the United States and 32,100 cases (92\%) of these cancers were attributable to HPV genotypes targeted by the 9-valent (9v) HPV vaccine, with 19,000 cases among females and 13,100 cases among males [4]. Therefore, bivalent (2v) HPV vaccine, which covers HPV 16/18; 4-valent (4v) HPV vaccine, which covers HPV 6/11/16/18; and 9v HPV vaccine, which covers HPV 6/11/16/18/31/33/45/52/58 were recommended for all boys and girls at 11-12 years old in the United States [5]. HPV vaccination has potential not only to prevent HPV-associated diseases in males but also to contribute to herd immunity by the reduction of HPV infection spreading in males and females [6-8]. To assess whether existing HPV vaccines are effective for Japanese males, investigating prevalence, genotype distribution, and risk factors among Japanese males against HPV infections targeted by the $2 \mathrm{v}, 4 \mathrm{v}$, and 9v HPV vaccines is essential. We have already reported the prevalence rate of HPV infection among Japanese males, especially for elderly people [9]. As a sub-analysis of the previous study, we conducted further analysis to determine the genotype distribution and predictors of HPV infections targeted by $2 \mathrm{v}, 4 \mathrm{v}$, and 9v HPV vaccines among Japanese male patients who visited our urological clinics.

\section{Materials and Methods}

\subsection{Ethical Issues}

All protocols and assessments in this study were approved by the ethics committees of Asoka Hospital (ID: 00008) and Nagareyama Central Hospital (ID: 00001) in Tokyo. Written informed consent was obtained from all participants in this study.

\subsection{Sample Collection}

The method of sample collection was reported previously [9]. In brief, we recruited 872 male patients aged 20 to 94 years who visited our urological clinics (Asoka Hospital and Nagareyama Central Hospital) from September 2011 to October 2015. Scraping samples from the glans penis were collected by the urologists with a wet cotton swab at least twice. For patients with phimosis, the urologists inserted a wet cotton swab inside the foreskin to collect scraping samples.

\subsection{Questionaieres}

The questionnaires included their age, educational status, smoking status, sexual orientation, number of lifetime sex partners, age at sex initiation, marital status, history of divorce, existence of current sex partners, and the presence or history of a sexually transmitted infection (STI).

\subsection{Genotyping Analysis}

One-mL aliquots of preservative solution containing scraping samples were centrifuged at $5000 \mathrm{rpm}$ for $5 \mathrm{~min}$, and the supernatant was discarded. The cell pellet was washed twice with $300 \mu \mathrm{L}$ of $10 \mathrm{mmol} / \mathrm{L}$ Tris- $\mathrm{HCl}$ (pH 8.0). Deoxyribonucleic acid (DNA) was extracted from the cells using DNA extraction kit (SMI test, G \& G Science Co., Fukushima, Japan). The genotype of HPV DNA and $\beta$-globin were assessed at the LSI Medience Corporation (Tokyo, Japan) using the GENOSEARCH HPV31 kit (Medical and Biological Laboratory, Nagoya, Japan) following the manufacturer's instructions [10]. The assessment kit can detect the following 31 genotypes of HPV DNA: HR genotypes $(16,18,31$, $33,35,39,45,51,52,56,58,59,68,73$, and 82) and LR genotypes $(6 \mathrm{~b}, 11,26,42,44,53,54,55,61,62$, $66,70,71,84,90$, and CP6108) by combination of multiplex polymerase chain reaction and Luminex technology $[11,12]$. It also assessed human $\beta$-globin to ensure that scraping samples from the glans penis contained enough cellular components.

\subsection{Statistical Analysis}

Statistical analyses in this study were performed using a JMP Pro software version 14 (SAS, Cary, NC, USA). A logistic regression analysis was used for detecting risk factors of HPV infection. The same 
control group (HPV negative plus $\beta$-globin positive cases) was used in all logistic regression analysis. $p$ values $<0.05$ were considered statistically significant.

\section{Results and Discussion}

Of the 872 scraping samples, $\beta$-globin was positive in 798 samples (91.5\%). The characteristics of the participants, after excluding those who had negative $\beta$-globin are summarized in Table 1 . The prevalence of HPV infection in our cohort is shown in Table 2. One hundred ninety-eight participants (198/798; 24.8\%) had at least one type of any HPV infection. The total number of males with HPV infection targeted by $2 \mathrm{v}, 4 \mathrm{v}$, and $9 \mathrm{v}$ were 20,35 , and 79 , respectively.

The total number of HPV genotypes detected in this study was 328. Of the 328 HPV genotypes, $138(42.1 \%)$ were HR HPV and $190(57.9 \%)$ were LR HPV. The most frequently detected types of HR and LR HPV infections were type $52(\mathrm{n}=40 ; 40 / 328 ; 12.2 \%)$ and type $90(\mathrm{n}=26 ; 26 / 328 ; 7.9 \%)$, respectively. HPV genotypes 16, 18, 31, 33, 45, 52, and 58 were detected in $13,7,5,1,3,40$, and 8 participants, respectively. The number of HPV genotypes 6 and 11 were detected in 13 and 9 participants, respectively (three of the 19 participants were exposed to both types). Of the 19 participants exposed to HPV types $6 \mathrm{~b}$ or 11 , six participants (31.6\%) suffered from condyloma acuminatum. Total number of detected HPV genotypes targeted by 9v HPV vaccine was 99 (99/328; 30.2\%) (Figure 1). All the detected HPV genotypes and numbers are shown in Table 2; especially 9v HPV was drawn as a pie chart in Figure 2.

In 2013, Lenzi et al. reviewed five reports regarding the prevalence of HPV infection among patients attending the sexually transmitted disease clinic [13]. They reported that the prevalence of any HPV infection was 13.2\% in Sweden [14], 44.9\% in Denmark [15], 28.2\% in the USA [16], 28.2\% in the Netherlands [17], and 5.9\% in Japan [18]. Regarding racial differences, Akogbe et al. reported that the prevalence of any HPV infection was significantly lower among Asians/Pacific Islander men (42.3\%) compared to black $(66.2 \%)$, Mexican $(62.3 \%)$, and white $(71.5 \%)$ men $(p<0.0001)$ [19]. Similar to the previous reports, the prevalence of any HPV infection among Japanese males in our study $(24.8 \%)$ was relatively lower rather than other races because of fewer numbers of lifetime sexual partners. The most detected type of HPV among men was type 62 in Brazil (10.7\%), type 59 in Mexico (7.2\%), type 83 in the USA (7.2\%) [20], and type 56 in Kenya (6.3\%) [21]. According to the data of the British National Survey of Sexual Attitudes and Lifestyles, HPV DNA was detected in $17.4 \%$ and $29.0 \%$ of men and women, respectively [22]. In the study, the most detected HPV type was type 16 (2.3\% and $4.2 \%$ of men and women, respectively). HPV type 52 was previously reported to be the most detected genotype $(4.8 \%)$, which was also reported to be the most frequently detected genotype among young Japanese females $[10,23]$. In our study, HPV type 52 was the most frequently detected HR genotype among Japanese males.

In the multivariate logistic regression analysis, which included all cofounders that might interfere with each other, having $\geq 21$ lifetime sex partners or a current or past STI were significant predictors against HPV infection with adjusted odds ratios (ORs) of 3.106 (95\% confidence interval (CI), 1.593-6.059) and 1.894 (95\% CI, 1.185-3.026), respectively (Table 3). Age of sex initiation ( $\leq 19$ years) was a significant predictor against HPV infection targeted by $2 \mathrm{v}$ and $4 \mathrm{v}$ HPV vaccines with adjusted ORs of 5.100 (CI, 1.013-25.673; Table 4) and 2.676 (CI, 1.037-6.905; Table 5), respectively. Number of lifetime sex partners ( $\geq 21$ persons) was a significant predictor against HPV infection targeted by $9 \mathrm{v}$ HPV vaccine with adjusted ORs of 2.397 (CI, 1.060-5.424; Table 6). Number of lifetime female sex partners was reported to be associated with HPV infection among male [24,25]. A younger age at first sexual intercourse also became a risk of HPV infection [25,26]. Smoking $[26,27]$ was reported to aggravate risk of HPV infection; however, smoking was not associated with HPV infection in our cohort.

Since April 2013, HPV vaccinations have been recommended for girls aged 13 to 16 years in Japan; the aggressive recommendation of HPV vaccinations had been withheld for 10 weeks because adverse events, such as a long-term pain, numbness, and autoimmune diseases, had occurred in some vaccinated girls [28]. The efficacy and safety of HPV vaccination for Japanese males has been 
revealed in clinical trial recently [29]. Therefore, gender-neutral vaccination should be recommended in our society.

Table 1. Characteristics of study participants.

\begin{tabular}{|c|c|}
\hline Characteristics & n OR Mean \pm SD \\
\hline Age, years & $55.4 \pm 19.5$ \\
\hline \multicolumn{2}{|l|}{ Age group (years), $\mathrm{n}$} \\
\hline All & 798 \\
\hline $20-29$ & 101 \\
\hline $30-39$ & 108 \\
\hline $40-49$ & 114 \\
\hline $50-59$ & 118 \\
\hline $60-69$ & 114 \\
\hline $70-79$ & 138 \\
\hline$\geq 80$ & 105 \\
\hline \multicolumn{2}{|l|}{ Educational status, $\mathrm{n}$} \\
\hline$\leq 12$ years & 372 \\
\hline$>12$ years & 412 \\
\hline Unknown & 14 \\
\hline \multicolumn{2}{|l|}{ Smoking status, $\mathrm{n}$} \\
\hline Current & 268 \\
\hline Previous & 9 \\
\hline Never & 503 \\
\hline Unknown & 18 \\
\hline \multicolumn{2}{|l|}{ Sexual orientation, $\mathrm{n}$} \\
\hline Female & 754 \\
\hline Male/Bisexual & 13 \\
\hline Unknown & 31 \\
\hline \multicolumn{2}{|c|}{ Number of lifetime sex partners, $n$} \\
\hline Median (range) & $5(0$ to 1500$)$ \\
\hline 0 to 10 & 678 \\
\hline 11 to 20 & 62 \\
\hline$\geq 21$ & 50 \\
\hline Unknown & 8 \\
\hline \multicolumn{2}{|l|}{ Age of sex initiation, years } \\
\hline Mean \pm SD & $20.8 \pm 5.0$ \\
\hline$\leq 19$ & 325 \\
\hline$\geq 20$ & 410 \\
\hline Unknown & 63 \\
\hline \multicolumn{2}{|l|}{ Marital status, $\mathrm{n}$} \\
\hline Single/Never married & 314 \\
\hline Married & 464 \\
\hline Divorced & 20 \\
\hline \multicolumn{2}{|c|}{ Sexual intercourse within a year, $\mathrm{n}(\%)$} \\
\hline Yes & 436 \\
\hline No & 333 \\
\hline Unknown & 29 \\
\hline \multicolumn{2}{|c|}{$\begin{array}{l}\text { Present or past history of sexually } \\
\text { transmitted infections, } \mathrm{n}\end{array}$} \\
\hline No & 679 \\
\hline Yes & 115 \\
\hline Unknown & 4 \\
\hline \multicolumn{2}{|c|}{ Types of Sexually transmitted infection, $\mathrm{n}$} \\
\hline Condyloma acuminatum & 11 \\
\hline Genital herpes & 10 \\
\hline Syphilis & 7 \\
\hline Gonococcal urethritis & 58 \\
\hline Chlamydial urethritis & 72 \\
\hline
\end{tabular}

SD, standard deviation. 
Table 2. The number of detected HPV genotypes among Japanese males.

\begin{tabular}{|c|c|c|c|}
\hline \multirow{2}{*}{ Types of HPV } & \multicolumn{3}{|c|}{ Number of Participants } \\
\hline & Single HPV, n & Multiple HPVs, n & Total, $\mathrm{n}$ \\
\hline \multicolumn{4}{|l|}{ High-Risk HPV } \\
\hline Type $16^{a, b, c}$ & 3 & 10 & 13 \\
\hline Type $18^{a, b, c}$ & 1 & 6 & 7 \\
\hline Type $31^{\mathrm{c}}$ & 0 & 5 & 5 \\
\hline Type $33^{c}$ & 0 & 1 & 1 \\
\hline Type 35 & 1 & 3 & 4 \\
\hline Type 39 & 6 & 7 & 13 \\
\hline Type $45^{c}$ & 1 & 2 & 3 \\
\hline Type 51 & 5 & 10 & 15 \\
\hline Type $52^{\mathrm{c}}$ & 17 & 23 & 40 \\
\hline Type 56 & 6 & 6 & 12 \\
\hline Type $58^{c}$ & 3 & 5 & 8 \\
\hline Type 59 & 3 & 1 & 4 \\
\hline Type 68 & 5 & 4 & 9 \\
\hline Type 73 & 1 & 0 & 1 \\
\hline Type 82 & 2 & 1 & 3 \\
\hline \multicolumn{4}{|l|}{ Low-risk HPV } \\
\hline Type $6 \mathrm{~b}$ b,c & 5 & 8 & 13 \\
\hline Type 11 b,c & 3 & 6 & 9 \\
\hline Type 26 & 0 & 1 & 1 \\
\hline Type 42 & 5 & 9 & 14 \\
\hline Type 44 & 3 & 4 & 7 \\
\hline Type 53 & 6 & 11 & 17 \\
\hline Type 54 & 3 & 1 & 4 \\
\hline Type 55 & 1 & 5 & 6 \\
\hline Type 61 & 4 & 9 & 13 \\
\hline Type 62 & 8 & 11 & 19 \\
\hline Type 66 & 2 & 11 & 13 \\
\hline Type 70 & 1 & 7 & 8 \\
\hline Type 71 & 11 & 12 & 23 \\
\hline Type 84 & 3 & 7 & 10 \\
\hline Type 90 & 13 & 13 & 26 \\
\hline Type СР6108 & 4 & 3 & 7 \\
\hline
\end{tabular}

Single HPV: Only one genotype was detected in one participant. Multiple HPVs: More than two genotypes were detected in one participant. The genotype targeted by ${ }^{a} 2 \mathrm{v},{ }^{b} 4 \mathrm{v}$, and ${ }^{\mathrm{c}} 9 \mathrm{v}$.

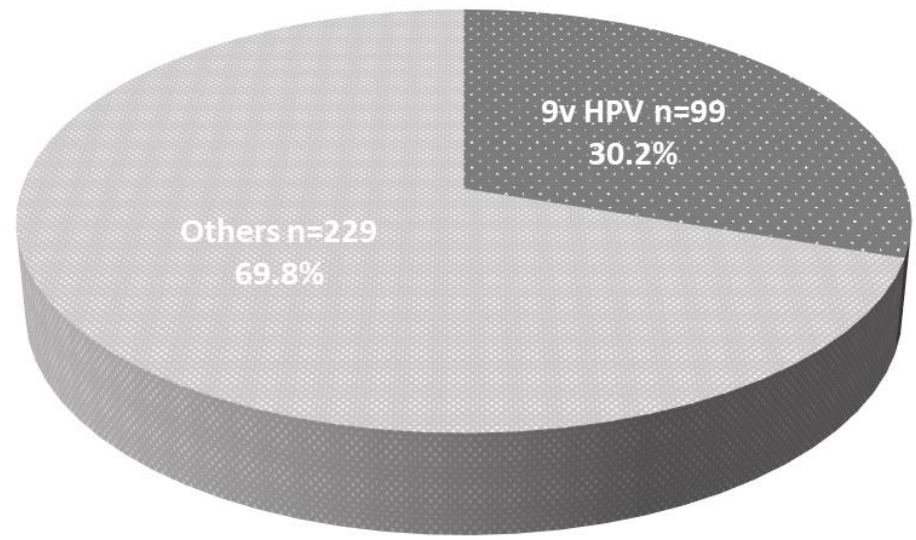

Figure 1. The detection rate of $9 \mathrm{v}$ human papilloma virus (HPV) among Japanese male sampling: Of 328 genotypes, $30.2 \%$ (99/328) were covered by the $9 v$ HPV vaccine. 


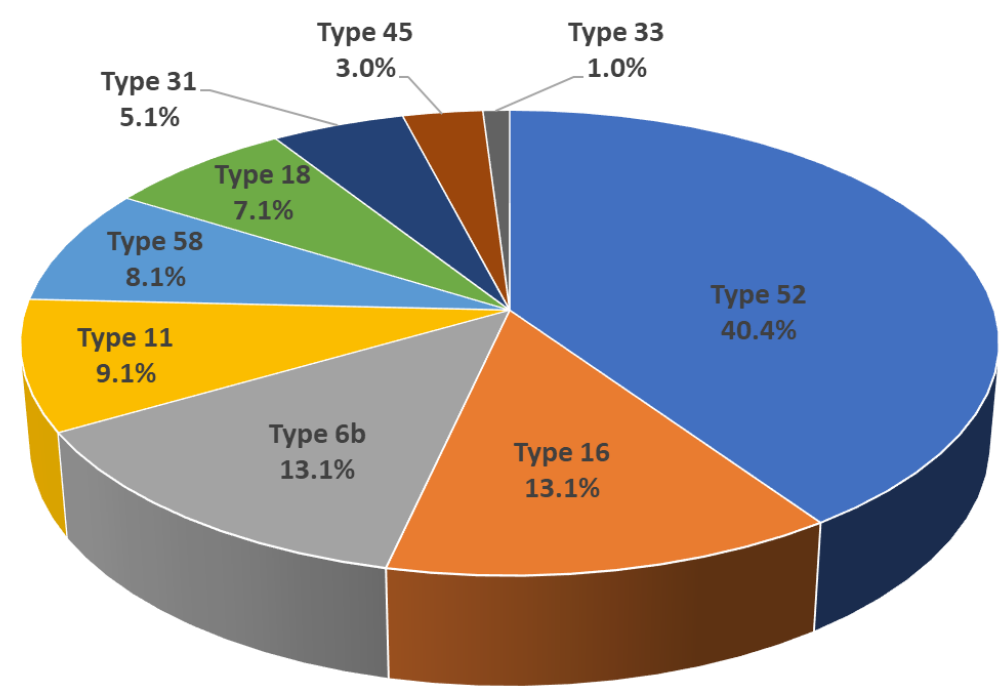

Figure 2. The detection rate among 9v HPVs: Type 52 was the most detected genotype $(\mathrm{n}=40$; $40 / 99 ; 40.4 \%$ ).

Table 3. Predictors against any HPV infection.

\begin{tabular}{|c|c|c|}
\hline Variables & Crude OR $(95 \%$ CI $)$ & Adjusted OR * $(95 \% \mathrm{CI})$ \\
\hline Age, continuous & $1.010(1.002-1.019)$ & $1.004(0.991-1.017)$ \\
\hline \multicolumn{3}{|l|}{ Educational status } \\
\hline$\leq 12$ years & Reference & Reference \\
\hline 12 years & $0.948(0.685-1.311)$ & $0.914(0.627-1.334)$ \\
\hline \multicolumn{3}{|l|}{ Smoking status } \\
\hline Never & Reference & Reference \\
\hline Current & $1.670 * *(1.195-2.333)$ & $1.091(0.742-1.604)$ \\
\hline Former & $0.457(0.057-3.695)$ & $0.522(0.060-4.164)$ \\
\hline \multicolumn{3}{|l|}{ Sexual orientation } \\
\hline Female & Reference & Reference \\
\hline Male/Bisexual & $1.929(0.623-5.969)$ & $1.372(0.382-4.917)$ \\
\hline \multicolumn{3}{|c|}{ Number of lifetime sex partners } \\
\hline 0 to 10 & Reference & Reference \\
\hline 11 to 20 & $2.058^{* *}(1.185-3.574)$ & $1.343(0.736-2.453)$ \\
\hline$\geq 21$ & $5.167^{* *}(2.861-9.331)$ & $3.106^{* *}(1.593-6.059)$ \\
\hline \multicolumn{3}{|l|}{ Age of sex initiation } \\
\hline$\geq 20$ years & Reference & Reference \\
\hline$<19$ years & $2.114^{* *}(1.510-2.960)$ & $1.480(0.996-2.201)$ \\
\hline \multicolumn{3}{|l|}{ Marital status } \\
\hline Single/Never married & Reference & Reference \\
\hline Married & $1.180(0.843-1.653)$ & $1.231(0.820-1.848)$ \\
\hline Divorced & $2.282(0.898-5.799)$ & $2.162(0.780-5.992)$ \\
\hline \multicolumn{3}{|c|}{ Sexual intercourse within a year, $n$} \\
\hline No & Reference & Reference \\
\hline Yes & $1.282(0.926-1.784)$ & $1.295(0.821-2.042)$ \\
\hline \multicolumn{3}{|c|}{ Present or past history of STIs } \\
\hline No & Reference & Reference \\
\hline Yes & $2.799^{* *}(1.860-4.197)$ & $1.894^{* *}(1.185-3.026)$ \\
\hline
\end{tabular}

STI, sexually transmitted infection; OR, odds ratio; $\mathrm{CI}$, confidence interval. ${ }^{*}$ Multivariate analysis was performed with all variables. ${ }^{* *}$ OR had significant differences $(p<0.05)$. 
Table 4. Predictors against HPV infection targeted by the $2 \mathrm{v}$ HPV vaccine.

\begin{tabular}{|c|c|c|}
\hline Variables & Crude OR $(95 \%$ CI $)$ & Adjusted OR * $(95 \%$ CI $)$ \\
\hline Age, continuous & $1.011(0.988-1.034)$ & $0.995(0.957-1.036)$ \\
\hline \multicolumn{3}{|l|}{ Educational status } \\
\hline$\geq 12$ years & Reference & Reference \\
\hline$<12$ years & $1.236(0.497-3.078)$ & $1.155(0.376-3.550)$ \\
\hline \multicolumn{3}{|l|}{ Smoking status } \\
\hline Never & Reference & Reference \\
\hline Current & $0.659(0.257-1.691)$ & $0.768(0.254-2.327)$ \\
\hline Former & NA & NA \\
\hline \multicolumn{3}{|l|}{ Sexual orientation } \\
\hline Female & Reference & Reference \\
\hline Male/Bisexual & $0.276(0.034-2.251)$ & $0.241(0.023-2.567)$ \\
\hline \multicolumn{3}{|c|}{ Number of lifetime sex partners } \\
\hline 0 to 10 & Reference & Reference \\
\hline 11 to 20 & $0.239 * *(0.074-0.774)$ & $0.384(0.103-1.427)$ \\
\hline$\geq 21$ & $0.258 * *(0.70-0.958)$ & $0.654(0.138-3.094)$ \\
\hline \multicolumn{3}{|l|}{ Age of sex initiation } \\
\hline$\geq 20$ years & Reference & Reference \\
\hline$<19$ years & $4.569^{* *}(1.489-14.017)$ & $5.100 * *(1.013-25.673)$ \\
\hline \multicolumn{3}{|l|}{ Marital status } \\
\hline Single/Never married & Reference & Reference \\
\hline Married & $1.215(0.498-2.968)$ & $0.865(0.268-2.792)$ \\
\hline Divorced & NA & NA \\
\hline \multicolumn{3}{|c|}{ Sexual intercourse within a year, $\mathrm{n}$} \\
\hline No & Reference & Reference \\
\hline Yes & $0.496(0.175-1.405)$ & $0.829(0.177-3.872)$ \\
\hline \multicolumn{3}{|c|}{ Present or past history of STIs } \\
\hline No & Reference & Reference \\
\hline Yes & $0.382(0.143-1.017)$ & $0.418(0.127-1.381)$ \\
\hline
\end{tabular}

STI, sexually transmitted infection; OR, odds ratio; CI, confidence interval; NA, not available. ${ }^{*}$ Multivariate analysis was performed with all variables. ${ }^{* *}$ OR had significant differences $(p<0.05)$.

Table 5. Predictors against HPV infection targeted by the $4 \mathrm{v}$ HPV vaccine.

\begin{tabular}{lcc}
\hline \multicolumn{1}{c}{ Variables } & Crude OR (95\% CI) & Adjusted OR * (95\% CI) \\
\hline Age, continuous & $0.981(0.963-0.998)$ & $0.987(0.959-1.016)$ \\
\hline $\begin{array}{l}\text { Educational status } \\
\leq 12 \text { years }\end{array}$ & Reference & Reference \\
$>12$ years & $1.016(0.511-2.024)$ & $1.108(0.483-2.544)$ \\
\hline Smoking status & Reference & \\
Never & $1.815(0.902-3.653)$ & Reference \\
Current & NA & $1.553(0.688-3.508)$ \\
Former & NA \\
\hline Sexual orientation & Reference & Reference \\
Female & $1.880(0.237-14.91)$ & $1.906(0.194-18.73)$ \\
Male/Bisexual & & Reference \\
\hline Number of lifetime sex partners & Reference & $1.396(0.463-4.216)$ \\
0 to 10 & $2.390(0.879-6.503)$ & $1.125(0.305-4.159)$ \\
11 to 20 & $2.370(0.789-7.118)$ &
\end{tabular}


Table 5. Cont.

\begin{tabular}{|c|c|c|}
\hline Variables & Crude OR $(95 \%$ CI) & Adjusted OR * $(95 \% \mathrm{CI})$ \\
\hline \multicolumn{3}{|l|}{ Age of sex initiation } \\
\hline$\geq 20$ years & Reference & Reference \\
\hline$<19$ years & $3.393(1.548-7.439)$ & $2.676^{* *}(1.037-6.905)$ \\
\hline \multicolumn{3}{|l|}{ Marital status } \\
\hline Single/Never married & Reference & Reference \\
\hline Married & $2.234 * *(1.087-4.593)$ & $2.190(0.895-5.360)$ \\
\hline Divorced & $0.365(0.098-1.356)$ & NA \\
\hline \multicolumn{3}{|c|}{ Sexual intercourse within a year, $n$} \\
\hline No & Reference & Reference \\
\hline Yes & $1.556(0.743-3.255)$ & $1.081(0.392-2.982)$ \\
\hline \multicolumn{3}{|c|}{ Present or past history of STIs } \\
\hline No & Reference & Reference \\
\hline Yes & $2.491 * *(1.163-5.337)$ & $2.136(0.860-5.304)$ \\
\hline
\end{tabular}

STI, sexually transmitted infection; OR, odds ratio; CI, confidence interval; NA, not available. * Multivariate analysis was performed with all variables. ${ }^{* *}$ OR had significant differences $(p<0.05)$.

Table 6. Predictors against HPV infection targeted by the 9v HPV vaccine.

\begin{tabular}{|c|c|c|}
\hline Variables & Crude OR $(95 \%$ CI) & Adjusted OR * $(95 \% \mathrm{CI})$ \\
\hline Age, continuous & $0.984(0.972-0.996)$ & $0.986(0.967-1.005)$ \\
\hline \multicolumn{3}{|l|}{ Educational status } \\
\hline$\leq 12$ years & Reference & Reference \\
\hline$>12$ years & $0.817(0.508-1.316)$ & $0.752(0.434-1.303)$ \\
\hline \multicolumn{3}{|l|}{ Smoking status } \\
\hline Never & Reference & Reference \\
\hline Current & $1.796(1.115-2.894)$ & $1.148(0.659-1.999)$ \\
\hline Former & NA & NA \\
\hline \multicolumn{3}{|l|}{ Sexual orientation } \\
\hline Female & Reference & Reference \\
\hline Male/Bisexual & $1.722(0.374-7.922)$ & $1.215(0.222-6.644)$ \\
\hline \multicolumn{3}{|c|}{ Number of lifetime sex partners } \\
\hline 0 to 10 & Reference & Reference \\
\hline 11 to 20 & $2.315 * *(1.112-4.821)$ & $1.432(0.645-3.181)$ \\
\hline$\geq 21$ & $4.230^{* *}(2.117-8.453)$ & $2.397 * *(1.060-5.424)$ \\
\hline \multicolumn{3}{|l|}{ Age of sex initiation } \\
\hline$\geq 20$ years & Reference & Reference \\
\hline$<19$ years & $2.669 * *(1.607-4.433)$ & $1.590(0.876-2.890)$ \\
\hline \multicolumn{3}{|l|}{ Marital status } \\
\hline Single/Never married & Reference & Reference \\
\hline Married & $0.798(0.494-1.289)$ & $0.987(0.550-1.771)$ \\
\hline Divorced & $2.059(0.651-6.515)$ & $2.131(0.600-7.565)$ \\
\hline \multicolumn{3}{|c|}{ Sexual intercourse within a year, $\mathrm{n}$} \\
\hline No & Reference & Reference \\
\hline Yes & $2.166^{* *}(1.268-3.700)$ & $1.243(0.617-2.505)$ \\
\hline \multicolumn{3}{|c|}{ Present or past history of STIs } \\
\hline No & Reference & Reference \\
\hline Yes & $2.581 * *(1.507-4.421)$ & $1.788(0.960-3.329)$ \\
\hline
\end{tabular}

STI, sexually transmitted infection; OR, odds ratio; CI, confidence interval; NA, not available. * Multivariate analysis was performed with all variables. ${ }^{* *}$ ORs had significant differences $(p<0.05)$. 
The strength of our study included a large sample size of adult males of all ages. However, we did not obtain information regarding whether the participants had any sexual contact with commercial sex workers, and both Asoka Hospital and Nagareyama Center Hospital locate in urban areas, which might be the weakness of our study.

In conclusion, we found that approximately a quarter of Japanese male patients who visited the urological clinics were exposed to HPV and that some kinds of sexual behavior aggravate the risk of typical HPV infections.

\section{Conclusions}

Approximately a quarter of Japanese male patients who visited urological clinics were exposed to at least one type of HPV infection, and some kinds of sexual behavior (such as number of lifetime sex partners, age of sex initiation, and present or past history of STIs) were found to be predictors for typical HPV infections.

Author Contributions: T.K. designed this study; Y.M. and M.S. analyzed the data; Y.M., T.K., M.S., Y.K., and K.S. wrote the manuscript; Y.K., and T.K. collected scraping samples from participants' glans penis. All authors have read and agreed to the published version of the manuscript.

Funding: This research was completely funded by the Japanese Foundation for Sexual Health Medicine (Grant number: Heisei 29001).

Conflicts of Interest: The authors declare no potential conflicts of interest with respect to this research and authorship.

\section{References}

1. International Human Papillomavirus Reference Center. Available online: https://www.hpvcenter.se/human reference_clones/ (accessed on 1 March 2020).

2. Zur Hausen, H. Papillomaviruses and cancer: From basic studies to clinical application. Nat. Rev. Cancer 2002, 2, 342-350. [CrossRef]

3. Howley, P.M.; Schiller, J.T.; Lowy, D.R. Papillomaviruses. In Fields Virology, 6th ed.; Knipe, D.M., Howley, P.M., Eds.; Lippincott Williams \& Wilkins: Philadelphia, PA, USA, 2013; pp. 1662-1703.

4. Centers for Disease Control and Prevention: Human Papillomavirus-Vaccinating Boys and Girls. Available online: https://www.cdc.gov/hpv/parents/vaccine.html (accessed on 1 March 2020).

5. Centers for Disease Control and Prevention: Human Papillomavirus-Attributable Cancers-United States, 2012-2016. Available online: https://www.cdc.gov/mmwr/volumes/68/wr/mm6833a3.htm?s_cid=mm6833a3_ w (accessed on 1 March 2020).

6. Schmeler, K.M.; Sturgis, E.M. Expanding the benefits of HPV vaccination to boys and men. Lancet 2016, 387, 1798-1799. [CrossRef]

7. Lehtinen, M.; Apter, D. Gender-neutrality, herd effect and resilient immune response for sustainable impact of HPV vaccination. Curr. Opin. Obstet. Gynecol. 2015, 27, 326-332. [CrossRef]

8. Stanley, M. HPV vaccination in boys and men. Hum. Vaccines Immunother. 2014, 10, 2109-2111. [CrossRef]

9. Kitamura, T.; Suzuki, M.; Koyama, Y.; Shigehara, K. Long-term persistence of human papillomavirus in the skin of the glans penis of elderly men above 80 years of age. Int. J. STD AIDS 2018, 29, 552-556. [CrossRef] [PubMed]

10. Imai, H.; Nakao, H.; Shinohara, H.; Watarai, M.; Matsumoto, N.; Yamagishi, T.; Saito, M.; Kitamura, T. Prevalence, potential predictors, and genotype-specific prevalence of human papillomavirus infection among sexually active students in Japan. PLoS ONE 2015, 10, e0132462. [CrossRef]

11. Centers for Disease Control and Prevention: Epidemiology and Prevention of Vaccine-Preventable Diseases. Chapter 11: Human Papillomavirus. Available online: https://www.cdc.gov/vaccines/pubs/pinkbook/hpv. html (accessed on 1 March 2020). 
12. Ozaki, S.; Kato, K.; Abe, Y.; Hara, H.; Kubota, H.; Kubushiro, K.; Kawahara, E.; Inoue, M. Analytical performance of newly developed multiplex human papillomavirus genotyping assay using Luminex xMAP $^{\mathrm{TM}}$ technology (Mebgen ${ }^{\mathrm{TM}}$ HPV Kit). J. Virol. Methods 2014, 204, 73-80. [CrossRef] [PubMed]

13. Lenzi, A.; Mirone, V.; Gentile, V.; Bartoletti, R.; Ficarra, V.; Foresta, C.; Mariani, L.; Mazzoli, S.; Parisi, S.G.; Perino, A.; et al. Rome Consensus Conference-Statement; human papilloma virus diseases in males. BMC Public Health 2013, 13, 117. [CrossRef] [PubMed]

14. Wikström, A.; Popescu, C.; Forslund, O. Asymptomatic penile HPV infection: A prospective study. Int. J. STD AIDS 2000, 11, 80-84.

15. Svare, E.I.; Kjaer, S.K.; Worm, A.M.; Osterlind, A.; Meijer, C.J.L.M.; van den Brule, A.J.C. Risk factors for genital HPV DNA in men resemble those found in women: A study of male attendees at a Danish STD clinic. Sex. Transm. Infect. 2002, 78, 215-218. [CrossRef]

16. Baldwin, S.B.; Wallace, D.R.; Papenfuss, M.R.; Abrahamsen, M.; Vaught, L.C.; Kornegay, J.R.; Hallum, J.A.; Redmond, S.A.; Giuliano, A.R. Human Papillomavirus infection in men attending a sexually transmitted disease clinic. J. Infect. Dis. 2003, 187, 1064-1070. [CrossRef] [PubMed]

17. Van Doornum, G.J.; Prins, M.; Juffermans, L.H.; Hooykaas, C.; van den Hoek, J.A.; Coutinho, R.A.; Quint, W.G. Regional distribution and incidence of human papillomavirus infections among heterosexual men and women with multiple sexual partners: A prospective study. Genitourin Med. 1994, 70, 240-246. [CrossRef] [PubMed]

18. Takahashi, S.; Shimizu, T.; Takeyama, K.; Kunishima, Y.; Hotta, H.; Koroku, M.; Tanda, H.; Saka, T.; Nishimura, M.; Iwasawa, A.; et al. Detection of human papillomavirus DNA on the external genitalia of healthy men and male patients with urethritis. Sex. Transm. Dis 2003, 30, 629-633. [CrossRef] [PubMed]

19. Akogbe, G.O.; Ajidahun, A.; Sirak, B.; Anic, G.M.; Papenfuss, M.R.; Fulp, W.J.; Lin, H.Y.; Abrahamsen, M.; Villa, L.L.; Lazcano-Ponce, E.; et al. Race and Prevalence of Human Papillomavirus Infection Among Men Residing in Brazil, Mexico and the United States. Int. J. Cancer 2012, 131, E282-E291. [CrossRef]

20. Giuliano, A.R.; Lazcano-Ponce, E.; Villa, L.L.; Flores, R.; Salmeron, J.; Lee, J.H.; Papenfuss, M.R.; Abrahamsen, M.; Jolles, E.; Nielson, C.M.; et al. The human papillomavirus infection in men study: Human papillomavirus prevalence and type distribution among men residing in Brazil, Mexico, and the United States. Cancer Epidemiol. Biomark. Prev. 2008, 17, 2036-2043. [CrossRef]

21. Backes, D.M.; Snijders, P.J.F.; Hudgens, M.G.; Bailey, R.C.; Bogaarts, M.; Agot, K.; Agingu, W.; Moses, S.; Meijer, C.J.L.M.; Smith, J.S. Sexual behaviour and less frequent bathing are associated with higher human papillomavirus incidence in a cohort study of uncircumcised Kenyan men. Sex. Transm. Infect. 2013, 89, 148-155. [CrossRef]

22. Johnson, A.M.; Mercer, C.H.; Beddows, S.; de Silva, N.; Desai, S.; Howell-Jones, R.; Carder, C.; Sonnenberg, P.; Fenton, K.A.; Lowndes, C.; et al. Epidemiology of, and behavioural risk factors for, sexually transmitted human papillomavirus infection in men and women in Britain. Sex. Transm. Infect. 2012, 88, 212-217. [CrossRef]

23. Inoue, M.; Sakaguchi, J.; Sasagawa, T.; Tango, M. The evaluation of human papillomavirus DNA testing in primary screening for cervical lesions in a large Japanese population. Int. J. Gynecol. Cancer 2006, 16, 1007-1013. [CrossRef]

24. Davidson, C.L.; Richter, K.L.; Van-del-Linde, M.; Coetsee, J.; Boy, S.C. Prevalence of oral and oropharyngeal human papillomavirus in a sample of South African Men: A pilot study. S. Afr. Med. J. 2014, 104, 358-361. [CrossRef]

25. Giuliano, A.R.; Lazcano, E.; Villa, L.L.; Flores, R.; Salmeron, J.; Lee, J.H.; Papenfuss, M.; Abrahamsen, M.; Baggio, M.L.; Silva, R. Circumcision and sexual behavior: Factors independently associated with human papillomavirus (HPV) detection among Men in the HIM Study. Int. J. Cancer 2009, 124, 1251-1257. [CrossRef]

26. Lu, B.; Wu, Y.; Nielson, C.M.; Flores, R.; Abrahamsen, M.; Papenfuss, M.; Harris, R.B.; Giuliano, A.R. Factors associated with acquisition and clearance of human papillomavirus infection in a cohort of US Men: A prospective study. J. Infect. Dis. 2009, 199, 362-371. [CrossRef] [PubMed]

27. Nielson, C.M.; Harris, R.B.; Dunne, E.F.; Abrahamsen, M.; Papenfuss, M.R.; Flores, R. Risk factors for anogenital human papillomavirus infection in Men. J. Infect. Dis. 2007, 196, 1137-1145. [CrossRef] [PubMed] 
28. Gilmour, S.; Kanda, M.; Kusumi, E.; Tanimoto, T.; Kami, M.; Shibuya, K. HPV vaccination programme in Japan. Lancet 2013, 382, 768. [CrossRef]

29. Mikamo, H.; Yamagishi, Y.; Murata, S.; Yokokawa, R.; Han, S.R.; Wakana, A.; Sawata, M.; Tanaka, Y. Efficacy, Safety, and Immunogenicity of a Quadrivalent HPV Vaccine in Japanese Men: A Randomized, Phase 3, Placebo-Controlled Study. Vaccine 2019, 37, 1651-1658. [CrossRef] [PubMed]

(C) 2020 by the authors. Licensee MDPI, Basel, Switzerland. This article is an open access article distributed under the terms and conditions of the Creative Commons Attribution (CC BY) license (http://creativecommons.org/licenses/by/4.0/). 